\title{
Lectinhistochemical staining of granuloma induced by bacillus Calmette-Guerin in Piaractus mesopotamicus
}

\author{
Lectinhistoquímica del granuloma inducido por el bacilo de \\ Calmette Guérin en Piaractus mesopotamicus
}

\author{
Wilson G. Manrique, ${ }^{1}$ Ph.D, Gustavo S. Claudiano, ${ }^{1}$ M.Sc, Mayra AP. Figueiredo, ${ }^{1}$ M.Sc, \\ Thalita R. Petrillo, ${ }^{1}$ M.Sc, Paulo F. Marcusso, ${ }^{1}$ M.Sc, Eduardo J. Gimeno, ${ }^{2}$ Ph.D, Julieta RE. \\ Moraes, ${ }^{1}$ Ph.D, Flávio R. Moraes, ${ }^{1 *}$ Ph.D.
}

\begin{abstract}
${ }^{1}$ São Paulo State University, School of Agricultural and Veterinary Sciences, Department of Veterinary Pathology, Jaboticabal Campus. Via de acesso Prof. Paulo Donato Castellane s/n. Jaboticabal, SP 14884-900, Brazil. ${ }^{2}$ National University of La Plata Department Animal Pathology, Faculty of Veterinary Medicine, Buenos Aires - Argentina. Streets 60 and 118. La Plata, Argentina. *Corresponding: fruasmoraes@gmail.com
\end{abstract}

Recibido: Junio de 2013; Aceptado: Agosto de 2013.

\begin{abstract}
Objetive. This study was conducted to evaluate, by means of lectinhistochemistry (LHC), the expression of carbohydrates in granulomas induced by the bacillus Calmette-Guerin (BCG) in muscle tissue of Piaractus mesopotamicus after 33 days. Material and methods. Histological sections with $3 \mu \mathrm{m}$ thick were incubated with the following lectins :WGA (Wheat germ agglutinin), DBA (Dolichos biflorus agglutinin) and HPA (Helix pomatia agglutinin), and the results were evaluated by light microscopy. Results. Acid fast bacilli were stained by Ziehl Neelsen (ZN) and strong labeled by WGA in the cytoplasm of macrophages. Labeling with DBA was intense in fibroblasts and weak in macrophages. On the other hand, HPA binding was stronger in macrophages, especially in those that were in close contact with epithelioid cells, without evidence of binding to fibroblasts. The epithelioid cells were not labeled by the used lectins, but they were identified by Hematoxilin-Eosin (HE). The lectins labeled specific type saccharides in glycoproteins, as $\mathrm{N}$-acetylglucosamine present in bacilli and macrophages, as well as $\mathrm{N}$-acetyl-galactosamine in macrophages. The control group showed no inflammation or lectin binding. Conclusions. This technique may be useful in identifying receptors for WGA, DBA and the HPA lectins in epithelioid granuloma induced by BCG in P. mesopotamicus.
\end{abstract}

Key words: Glycans, granuloma, lectinhistochemistry, mycobacterium, teleost (Source: MeSH).

\section{RESUMEN}

Objetivo. El presente estudio fue realizado para evaluar por medio de lectinhistoquímica (LHC), la expresión de carbohidratos en granulomas inducidos por el bacilo de Calmette-Guérin (BCG) en músculo de Piaractus mesopotamicus después de 33 días. Materiales y métodos. Cortes histológicos de $3 \mu \mathrm{m}$ de grosor fueron incubados con las siguientes lectinas: WGA (Wheat germ aglutinin), DBA (Dolichos biflorus agglutin) y HPA (Helix pomatia agglutinin), y los resultados evaluados por medio de 
microscopia de luz. Resultados. Bacilos ácido resistentes fueron identificados por la tinción de Ziehl Neelsen(ZN). Se observó un marcaje intenso con WGA en el citoplasma de macrófagos. El marcaje con DBA fue intenso en fibroblastos y débil en macrófagos. Con la lectina HPA el marcaje fue intenso en macrófagos, principalmente en los que estaban en estrecho contacto con las células epitelióides, externamente se observó marcaje débil en fibroblastos. Las células epitelióides no fueron marcadas por las lectinas, pero fueron identificadas con la tinción de Hematoxilina-Eosina (HE). Las lectinas tuvieron un tipo de marcaje específico en algunos monosacáridos, como $\mathrm{N}$-acetilglucosamina presente en los bacilos y en macrófagos, y N-acetilgalactosamina en macrófagos. En el grupo control no fue observada inflamación así como tampoco marcaje con las lectinas. Conclusiones. Esta técnica resultó eficiente en la identificación de receptores para las lectinas WGA, DBA y HPA en el granuloma epitelióide inducido por BCG en P. mesopotamicus.

Palabras clave: Glucanos, granuloma, lectinohistoquímica, micobactéria, teleósteo (Fuente: MeSH).

\section{INTRODUCTION}

Lectins are proteins of non-immune origin which bind specifically and reversibly to sugars (1). Lectins are commonly found in plants, vertebrates, invertebrates and microbes (2-4).

Lectins with different specificities provide a sensitive histochemical detection system to characterized changes in glycosylation and carbohydrate expression in different diseases of humans and animals $(1,5,6)$. A comprehensive review on the applications of lectins in microbiology indicates that the method is useful, especially in clinical diagnostic laboratory (7). For example, the lectin wheat germ agglutinin (WGA), combined with a chromogenic substrate, could be used to accurately identify Neisseria gonorrhaeae and Neisseria meningitides (8). Besides, the lectin-carbohydrate interaction has been used as a fast and cheap technique for the demonstration and differentiation of some mycobacterial species in different animal species $(9,10)$.

Lectins can be employed for demonstration of microorganisms in tissue sections (11-14). Apparently, they have not been used much in fish tissues.

We have applied an innovative approach by using lectins as probes for identification of mycobacteria in Piaractus mesopotamicus (Pacu), a bony fish that is endemic to the Paraguay-Paraná River basin and that has been introduced by aquaculture activities into a wider area (15).

The objective of this study was to investigate the lectin binding in mycobacteria and cells of the immune granuloma induced by the bacillus Calmette-Guérinin Piaractus mesopotamicus.

\section{MATERIALS AND METHODS}

Animals. Twelve pacus (Piaractus mesopotamicus) (weighing $=120 \pm 5.0 \mathrm{~g}$ ) were randomly distributed in four $250 \mathrm{~L}$ aquariums, with artesian water and supplemental aeration.

Inflammation induction. Prior to inoculated, the pacus were previously anesthetized by immersion in alcohol benzocaine solution $(1: 10000 \mathrm{v} / \mathrm{v})$, with $20 \mu \mathrm{l}(40 \mathrm{mg} / \mathrm{mL})$ (number live bacilli over $2.0 \times 10^{6} \mathrm{CFU} / \mathrm{mg}$ of BCG strain Mureau Rio de Janeiro) in the lateral-dorsal muscular region, equidistant between the dorsal fin and the sagittal plane.

Collection. Nine inoculated and three control (un-inoculated) fish were collected after 33 days and killed by immersion in alcoholic solution of benzocaine (1:500 v/v) (Ethics Committee CEUAUnesp protocol no 020092/09). The inoculated muscles were collected, fixed in Bouin solution during 6 hours and routinely processed for embedding in paraffin, cut at $5 \mu \mathrm{m}$ thick sections and stained with hematoxylin-eosin (HE) and Ziehl-Neelsen (ZN).

Lectinhistochemistry (LHC). Paraffin embedded sections $(5 \mu \mathrm{m})$ were used. After dewaxing, sections were treated with hydrogen peroxide $0.3 \%$ in methanol for $30 \mathrm{~min}$ at room temperature (to inhibit the endogenous peroxidase), rinsed several times in 0.01M PBS $(\mathrm{pH} \mathrm{7.2)}$, and treated with bovine serum albumin $0.1 \%$ in PBS for $15 \mathrm{~min}$. The sections were then incubated for $1 \mathrm{~h}$ at room temperature with the following biotinylated lectins with different specificity, as follows: DBA (Dolichos biflorus, binding specificity a-D-GaINAc); WGA (Triticum vulgaris, binding specificity a-D-GIcNAcand NeuNAc) and HPA (Helix pomatia agglutinin, binding specificity $\mathrm{N}$-acetylgalactosamine (GalNAc) (Vector Laboratories, Burlingame, 
Ca, USA). The optimal lectin concentration was $(1: 400 \mathrm{v} / \mathrm{v})$ in PBS for all lectins. The slides were incubated with an avidin-biotinperoxidase complex $(A B C)$ (Vector) for $45 \mathrm{~min}$. The horseradish peroxidase was activated by incubation for 1-2 min with a diaminobenzidine commercial kit (Dako Cytomation, Carpinteria, CA, USA) and counterstained with Harris hematoxilin. Controls for lectin staining included: exposure to horseradish-peroxidase and sections without lectins.

Analysis. The observations were performed under light microscopy and image capture with a digital camera (Olympus DP72, Imaging software cellSens v.1.5).

\section{RESULTS}

The microscopic examination of the fragments of muscle in the control group stained with $\mathrm{HE}$ revealed normal skeletal muscle. In the inoculated group the presence of acid-fast bacilli (AFB) stained by $\mathrm{ZN}$ was evident. In the HE stained sections, the inoculums were observed in the center of the granuloma surrounded by epithelioid cells, macrophages, a conjunctive capsule consisting of fibroblasts and collagen, with some melanomacrophages. On the periphery of the capsule and conjunctiva, there were perivascular mononuclear cells with scant cytoplasm, nucleus with intensely colored condensed chromatin, compatible with lymphocytes. The distribution of epithelioid cells, macrophages, lymphocytes, melanomacrophages capsules with fibroblasts and collagen fibers constitute the granuloma, and maintain the inoculums isolated from the muscle tissue (Figure 1).

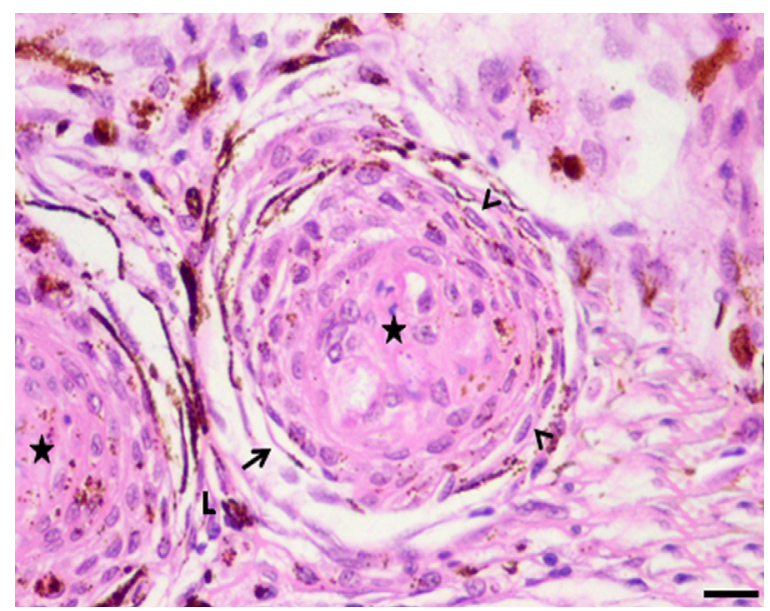

Figure 1. Photomicrograph of BCG-induced granuloma in muscle of Piaractus mesopotamicus after 33 days of inoculation. We observed the inoculums (star), fibroblasts (arrow), macrophages (arrowheads) and lymphocytes (L). HE. Bar= $20 \mu \mathrm{m}$.
The lectin WGA uniformly labeled bacilli in the inoculum and in the cytoplasm of macrophages. The epithelioid cells were not demonstrated by the lectins, but were distinguished by HE staining, constituting the first layers of cells in inflammatory granuloma (Figure 2).

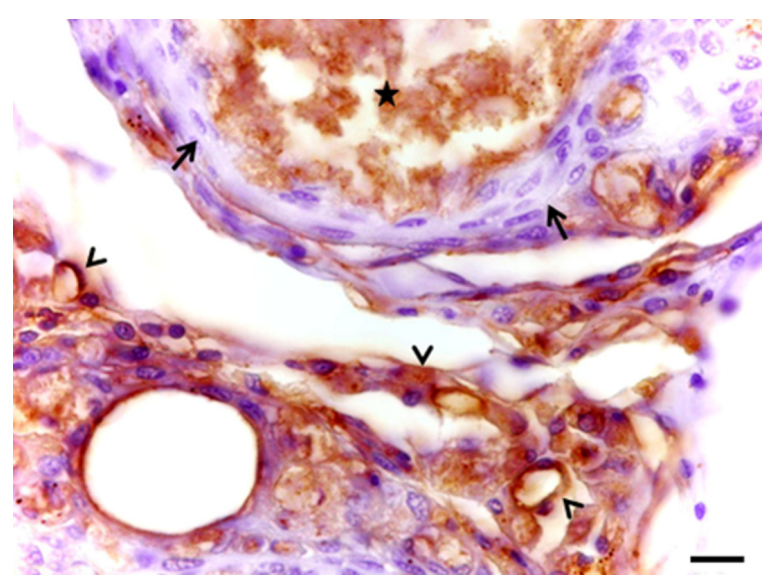

Figure 2. Photomicrograph of BCG-induced granuloma in muscle of Piaractus mesopotamicus after 33 days of inoculation. Note the inoculums labeled by WGA lectin (star), labeled macrophages (arrowhead) and no reaction to epithelioid cells (arrow). LHC. Bar $=10 \mu \mathrm{m}$.

The DBA labeling produced a strong reaction in fibroblasts and weak in macrophages (Figure 3), unlike the HPA, which had strong binding only in macrophages and reaction to fibroblasts (Figure 4).

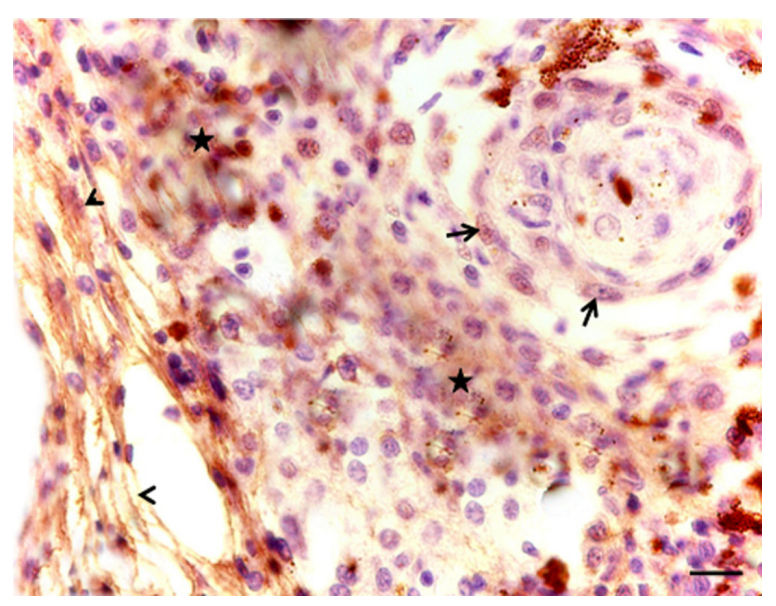

Figure 3. Photomicrograph of BCG-induced granuloma in muscle of Piaractus mesopotamicus after 33 days of inoculation. There is slight binding with DBA in macrophages (star) and strong reaction in fibroblasts (arrowhead), epithelioid cells were not labeled (arrow). LHC. Bar $=10 \mu \mathrm{m}$. 


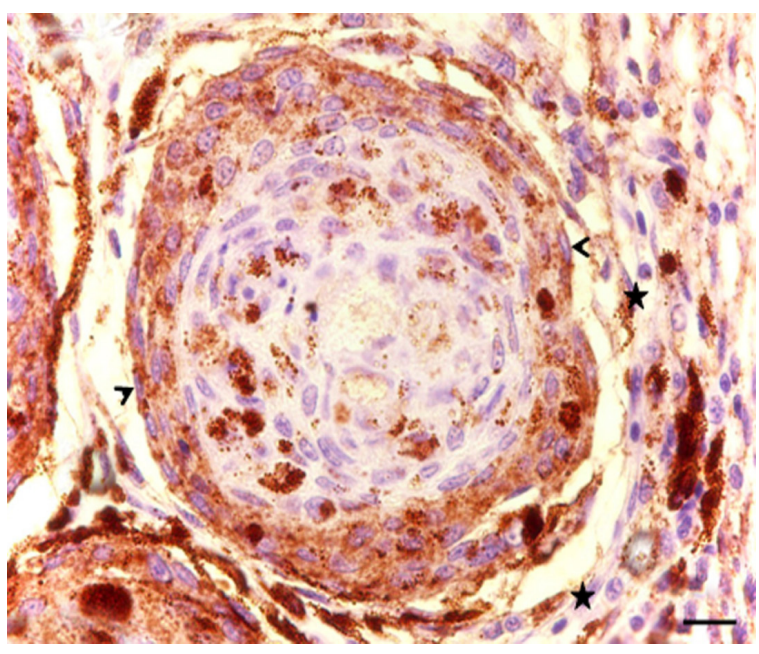

Figure 4. Photomicrograph of BCG-induced granuloma in muscle of Piaractus mesopotamicus after 33 days of inoculation. We observe strong reaction to the HPA in macrophages (arrowheads) and slight

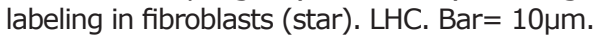

\section{DISCUSSION}

This study is the first to report the presence of receptors for the lectins WGA, DBA and HPA inimmune-type granulomatous inflammation in $P$. mesopotamicus. The chronic inflammatory process, after 33 days of evolution, was characterized as an epithelioid granuloma, similar to that reported by Manrique et al (16) by inoculation of BCG in P. mesopotamicus, as well as other mycobacteria in different fish (1719). Interestingly, the BCG induced different inflammation reaction depending on the fish species (20).

The establishment of mycobacteria in the host is conditioned by a wide range of conditions. This pathogenic relationship involves glycosylated molecules, proteins and lipids such as lipoarabinomanane (LAM) that form part of the bacterial wall. These products are necessary for binding to the macrophage mannose receptor (21), and secretion of glycoproteins such as the Apaprotein (Alanine Antigen Proline), which contributes to the adhesion and invasion of tissues by mycobacteria (22).

The cell wall of the bacillus and the macrophages express several saccharides, among them $\mathrm{N}$-acetyl-glucosamine which binds to WGA (23). The results of this study also show that the $\mathrm{N}$-acetyl-glucosamine expressed in epithelioid granuloma induced by BCG in $P$. mesopotamicus also reacts with the lectin WGA.
The DBA is a lectin that binds $\mathrm{N}$-acetylgalactosamine, but we have not found references of binding to macrophages and fibroblasts, as observed in this assay. This lectin have been use to label certain types of cells such as natural uterine killer lymphocytes of rats (UNK) (24). This reaction is due to the presence of granules of perforin and granzymes, and a variety of hydrolytic lysosomal enzymes (25).

In the latter case, they may be related to the binding of macrophages, since the expression and secretion of these substances is present due to their phagocytic activity (26). The reaction can be related to fibroblast glycosaminoglycan, localized on the cell surface that is recognized by this lectin. Then, the results of this trial suggest that the macrophages are labeled according to their lysosomal enzymes and fibroblasts due to the presence of superficial glycosaminoglycans.

In our study HPA labeled macrophages, but not other components of the epithelioid granuloma. This is probably due to the presence of $\mathrm{N}$-acetylgalactosamine, in resident macrophages as identified in human placenta (27) and dermal phagocytes in mice (28). Then, according to the results observed here, a similar phenomenon occurs with macrophages present in epithelioid granuloma induced by BCG. Macrophages have high phagocytic capacity and transform into epithelioid cells whose activity is predominantly secretory losing some of their surface receptors (29). In this assay epithelioid cells showed no labeling by lectin-dependent receptors for $\mathrm{N}$-acetyl-glucosamine and $\mathrm{N}$-acetylgalactosamine, probably lost when the highly phagocytic cells became secretory epithelioid cells.

Some studies in teleost fish report that the presence of lectin can recognize mannose, $\mathrm{N}$-acetyl-glucosamine, and glucose and others (30-34). In the present study, the lectins used did not recognize this type of receptors indicating that the cells present in chronic granulomatous inflammation do not express these carbohydrates.

In conclusion, this study demonstrated a lectin binding of WGA, DBA and HPA lectins on macrophages with phagocytic activity, and in BCG fibroblasts, induced epithelioid granuloma in Piaractus mesopotamicus.

Aside from, WGA demonstrate BCG in the granuloma, which can be a useful complement of $Z N$. The positive reaction to WGA with mycobacteria coincides with previous studies in other animal species (10). The bacteria-lectin 
interaction is a rapid, inexpensive and reliable tool to differentiate mycobacterium species in vitro (9). Additionally, lectin is adaptable to various methods of visualization and has been widely used in situ. Thus, lectinhistochemistry is potentially suitable to demonstrate and differentiate mycobacteria in tissue sections.

\section{Acknowledgements}

To the Research Support Foundation of the State of São Paulo (FAPESP - Process no. 2009/176407) and the National University of La Plata by the donation of the lectins.

\section{REFERENCES}

1. Lehmann F, Tiralongo E, Tiralongo J. Sialic acid-specific lectins: occurrence, specificity and function. Cell Mol Life Sci 2006; 63:1331-1354.

2. Kennedy JF, Palva PMG, Corella MTS, Cavalcanti MSM, Coelho LCBB. Lectins, versatile proteins of recognition: a review. Carbohydr Polym 1995; 26:219-230.

3. Lis $\mathrm{H}$, Sharon N. Lectin as molecules and as tools. Annu Rev Biochem 1986; 55:35-67.

4. Mody R, Joshi S, Chaney W. Use of lectins as diagnostic and therapeutic tools for cancer. J Pharmacol Toxicol Methods 1995; 33:1-10.

5. Wróblewski S, Berenson M, Kopečková $P$, Kopeček J. Biorecognition of HPMA copolymerlectin conjugates as na indicator of differentiation of cell surface glycoproteins in development, maturation, and diseases of human and rodent gastrointestinal tissues. J Biomed Mater Res 2000; 51:329-342.

6. Wróblewski S, Ríhová B, Rossmann P, Hudcovicz T, Reháková Z, Kopecková $P$, Kopecek J. The influence of a colonic microbiota on HPMA copolymer lectin conjugates binding in rodent intestine. J Drug Target 2001; 9:85-94.

7. Doyle RJ. Lectin-microorganism interactions. Slifkin (Eds.). New-York: Marcel Decker Inc.; 1994.

8. Doyle RJ, Nedjat-Haiem F, Keller KF, Frasch CE. Diagnostic value of interactions between members of the family Neisseriaceae and lectins. Clin Microbiol Newsl 1984; 19:383-387.

9. Athamna A, Cohen D, Athamna M., et al. Rapid identification of Mycobacterium species by lectin agglutination. J Microbiol Methods 2006; 65:209-215.
10. Massone AR, Martín AA, Ibargoyen GS, Ofek I, Stavri H. Immunohistochemical methods for the visualization of Mycobacterium paratuberculosis in bovine tissues. J vet med B 1990; 37:251-253.

11. Dutta S, Sinha B, Bhattacharya B, Chatterjee B, Mazumder S. Characterization of a galactose binding serum lectin from the Indian catfish, Clarias batrachus: possible involvement of fish lectins in differential recognition of pathogens. Comp Biochem Physiol C 2005; 141:76-84.

12. Gimeno EJ, Marino FP, Pérez Escalá S. Marcación lectinhistoquímica de Sporothricum schenkii en cortes de tejidos de cobayos. Rev Med Vet 1995; 76:274-276.

13. Karayannopoulou G, Weiss J, Damjanov I.Detection of fungi in tissue sections by lectinhistochemistry. Arch Pathol Lab Med $1988 ; 112: 746-748$.

14. Leal AF, Lopes NE, Clark AT., et al. Carbohydrate profiling of fungal cell wall surface glycoconjugates of Aspergillus species in brain and lung tissues using lectinhistochemistry. Med Mycol 2012; 50:756-759.

15. Severi W, Rantin FT, Fernandes MN.Structural and morphological features of Piaractus mesopotamicus (Holmberg, 1887) gills. Rev Brasil Biol 2000; 60:493-501.

16. Manrique GW, Claudiano SG, Castro PM, Figueiredo MAP, Petrillo TR, Mello $H$, Moraes JRE, Moraes FR. Inflamação crônica induzida por BCG em Piaractus mesopotamicus.[online] Florianópolis, SC Brasil: 2011. [Acces in 2013 April 12]. URL available in: http://www.sovergs.com.br/ site/38conbravet/resumos/701.pdf.

17. Chinabut S, Limsuwan C, Chanratchakool P. Mycobacteriosis in the snakehead, Channastriatus (Fowler). J Fish Dis 1990; 13:531-535. 
18. Colorni A, Avtalion R, Knibb W, Bergera E, Colornia B, Timanb B. Histopathology of sea bass (Dicentrarchus labrax) experimentally infected with Mycobacterium marinum and treated with streptomycin and garlic (Allium sativum) extract. Aquaculture 1998; 160:1-17.

19. Ramos P. Granulomatose visceral em dourada (Sparus aurata L.) de presumível etiologia micobacteriana. Rev Port Ciênc Vet 2000; 95:185-191.

20. Sado RY, Matushima, ER. Histopathological, immunohistochemical and ultrastructural evaluation of inflammatory response in Arius genus fish under experimental inoculation of BCG. Braz Arch Biol Technol 2008; 51:929-935.

21. Schlesinger LS, Kaufmann TM, Iyer S,Hull SR, Marchiando LK. Differences in mannose receptor mediated uptake of lipoarabinomannan from virulent and attenuated strains of Mycobacterium tuberculosis by human macrophages. J Immunol 1996; 157:4558-4575.

22. Horn $C$, Namane $A$, Pescher $P$, Rivière M, Romain F, Puzo G, Bârzu O, Marchal G. Decreased capacity of recombinant 45/47kDa molecules (Apa) of Mycobacterium tuberculosis to stimulate $\mathrm{T}$ Iymphocyte responses related to changes in their mannosylation pattern. J Biol Chem 1999; 274:32032-32030.

23. Khasnobis S, Escuyer VE, Chatterjee D. Emerging therapeutic targets in tuberculosis: post-genomic era. Expert Opin Ther Targets 2002; 6:21-40.

24. Chen Z, Zhang J, Hatta K, Lima PD, Yadi $H$, Colucci F, Yamada AT, Croy BA. DBALectin Reactivity Defines Mouse Uterine Natural Killer Cell Subsets with Biased Gene Expression. Biol Reprod 2012; 112:1-18.

25. Paffaro-Jr VA, Bizinotto MC, Joazeiro PP, Yamada AT.Subset classification of mouse uterine natural killer cells by DBA lectin reactivity. Placenta 2003; 24:479-488.

26. Kaminski NE, Roberts JF, Guthrie FE. A rapid spectrophotometric method for assessing macrophage phagocytic activity. Immunol Letters 1985; 10:329-31.
27. Mitchell BS, Schumacher U. The use of the lectinHelix pomatia agglutinin (HPA) as a prognostic indicator and as a tool in cancer research. Histol Histopathol 1999; 14:217-226.

28. Dupasquier M., Stoitzner P., Wan H. Cerqueira D, van Oudenaren A, Voerman JS, DendaNagai K, Irimura T, Raes G, Romani N, Leenen $\mathrm{PJ}$. The dermal microenvironment induces the expression of the alternative activation marker CD301/mMGL in mononuclear phagocytes, independent of IL-4/IL-13 signaling. J Leukoc Biol 2006; 80:838-849.

29. Mariano M.The experimental granuloma.A hypothesis to explain the persistence of the lesion. Rev Inst Med Trop São Paulo 1995; 37:161-176.

30. Ewart KV, Johnson SC, Ross NW. Identification of a pathogen-binding lectin in salmon serum. Comp Biochem Physiol C 1999; 123:9-15.

31. Ewart KV, Johnson SC, Ross NW. Lectins of the innate immune system and their relevance to fish health. J Mar Sci 2001; 59:380-385.

32. Nakao M, Kajiya T, Sato $Y$, Somamoto T, Kato-Unoki Y, Matsushita M, Nakata M, Fujita T, Yano TLectin pathway of bony fish complement: identification of two homologs of the mannose-binding lectin associated with MASP2 in the common carp (Cyprinus carpio). J immunol 2006; 177:5471-5479.

33. Ourth DD, Narra MB, Simco BA. Comparative study of mannose-binding C-type lectin isolated from channel catfish (Ictalurus punctatus) and blue catfish (Ictalurus furcatus). Fish Shellfish Immunol 2007; 23:1152-1160.

34. Silva CDC, Coriolano MC, Silva Lino MA, de Melo CM, de Souza Bezerra R, de Carvalho EV, Dos Santos AJ, Pereira VR, Coelho LC. Purification and characterization of a mannose recognition lectin from Oreochromis niloticus (Tilapia Fish): Cytokine production in mice splenocytes. Appl Biochem Biotechnol 2012; 166:424-435. 